http://journal.uin-alauddin.ac.id/index.php/lamaisyir

Publisher: Fakultas Ekonomi dan Bisnis Islam UIN Alauddin Makassar

\title{
Islamic Business Ethics Implementation Towards Sustainibility Of The Hajj And Umrah Business Travel Agency Of Makassar City
}

\author{
1Nurbayani, ${ }^{2}$ Muliana \\ 1,2Universitas Fajar \\ 1,2Jl. Prof. Abdurrahman Basalamah No. 101 Makassar \\ 1nurrahman260114@gmail.com,2mulianafachrul@gmail.com
}

Received: 21 November 2020; Revised: 19 Desember 2020; Published: 14 March 2021

\begin{abstract}
ABSTRAK
Penelitian ini dilakukan untuk menganalisis dan mengkonfirmasi bagaimana penerapan etika bisnis Islam dalam mewujudkan loyalitas jamaah dan kelangsungan usaha biro travel haji dan umrah di kota Makassar. Penelitian ini merupakan penelitian lapangan dengan menggunakan pendekatan kuantitatif, dan alat analisis Structural Equation Modeling (SEM) yakni PLS (Partial Least Square) dalam menganalisis pengaruh penerapan etika bisnis Islam terhadap kelangsungan usaha. Hasil riset ditemukan bahwa pengelola biro travel telah menerapkan etika bisnis Islam dalam menjalankan kegiatan operasionalnya diantaranya prinsip keesaan, prinsip keadilan, prinsip bertanggung jawab serta prinsip kebenaran yang cukup tinggi sehingga mampu mewujudkan kelangsungan usaha atau eksistensi biro travel haji dan umrah di kota Makassar terutama yang dijadikan sampel dalam penelitian ini. Hasil riset ini merupakan informasi yang sangat menggembirakan bagi para calon jamaah haji dan umrah di kota Makassar.
\end{abstract}

Kata Kunci: Keberlanjutan; Etika; Bisnis; Haji dan Umrah.

\section{ABSTRACK}

Islamic business ethics implementation could control every business activity. This research was conducted to analyze and confirm how the Islamic business ethics implementation in realizing Hajj loyalty and business sustainibilty of Hajj and Umrah travel agencies in Makassar city. This research was a direct research using a quantitative approach, and used Structural Equation Modeling (SEM) as analysis tool which is PLS (Partial Least Square) in analyzing the effect of the Islamic business ethics implementation toward business sustainibility. The results of the research found that travel agency managers had implemented Islamic business ethics in operating its operational activities including the oneness, the justice, the responsibility and the truth principle which were quite high so it was able to realize business sustainibility or the existence of a travel agency for Hajj and Umrah Makassar city, especially those whom became sample in this study. The results of this research were very encouraging information for the Hajj and Umrah in Makassar city.

Key Words: Sustainibility; Ethics; Business;Hajj And Umrah. 


\section{PENDAHULUAN}

Umat Islam, dianjurkan serta diajarkan kepada semua pemeluknya untuk menjalankan kegiatan ekonomi sesuai peraturan, norma serta etika bisnis Islam. Tujuan etika bisnis Islam yakni mengajarkan kepada para pelaku bisnis dalam membentuk partnership secara gotong-royong atau tolong-menolong dan menghindari hal-hal yang tidak sejalan dengan prinsip-prinsip Syariah (Qordhowi, 1993). Fungsi Etika bisnis Islam dapat mengontrol setiap aktivitas bisnis. Etika bisnis Islam merupakan suatu kombinasi bisnis dengan nilai etika ditambah dengan nilai spiritual (agama). Menjalankan bisnis secara Syariah berarti menjalankan bisnis secara santun, menjalin kebersamaan yang Islami serta penuh penghormatan atas hak dan kewajiban masing-masing pihak. Syari"at Islam etika bisnis merupakan prilaku dalam mengoperasikan bisnis telah sesuai dengan ajaran atau nilai-nilai Islam, sehingga tidak perlu merasa kwatir dalam menjalankan usahanya karena telah diyakini bahwa hal tersebut merupakan suatu hal yang benar lagipula baik. Sebagaimana firman Allah Swt dalam QS An Nisa Ayat 29, (Agama, 2012). Idealnya, keimanan dan ketaatan umat Islam kepada Allah Swt selalu tercermin dalam aktivitasnya. Hal itu dimungkinkan dengan tertanamnya etika moral yang tinggi dalam diri seorang muslim, karena etika dan kode moral dalam Islam merupakan bagian dari keseluruhan keimanan Islam Bersama Orientasi akhirat sebagai tujuan akhir dari segala aktivitas, yaitu beribadah, dengan demikian kode etik dan moral Islam menciptakan rasa tanggung jawab dan akuntabilitas, baik bagi pembeli atau penjual (Sabahuddin, 2005)

Islam memandang bisnis Astrustworthy ('Amanah) bagi para pelaku usaha Muslim, kegiatan bisnis adalah bidang forworship (selain mencari untung). Itu wajib bagi seorang Muslim berkinerja sebaik mungkin dalam pekerjaannya dan berbuat adil dalam bisnisnya, karena semuanya akan diperhitungkan di akhirat. Apalagi, bisnis juga mengandung Misi untuk memuaskan kepentingan umum (maslahah), maka dua hal harus berjalan seiring tangan, untuk mencapai manfaat dunia dan akhirat (falah) (Rahmad, Hakim \& Elvan, 2012). Bisnis travel haji dan umrah dapat menarik perhatian para pelaku bisnis. Mengingat umat Islam yang secara keinginan sudah sangat rindu untuk berangkat ke tanah suci, dan menjadi tamu-tamunya Allah Swt. dhuyuf ar-rahman (Fadilah, 2019). Akan tetapi dikarenakan kuota, atau jangka waktu yang relatif lama, maka hal ini tidak mengurungkan niat mereka untuk tetap bertamu ke rumah Allah Swt. di Makkah al-Mukarramah. Haji adalah ibadah khusus yang berkaitan erat dengan waktu, yakni pada bulan zul hijjah saja, maka cara yang ditempuh adalah dengan 
terlebih dahulu melakukan umrah untuk sampai ke kota Mekkah dan Madinah, dengan melakukan ibadah umrah, yang mayoritas ulama menyatakan atau berpendapat hukumnya adalah sunah (Ath-Thabary, 2001). Berbicara mengenai haji dan umroh salah satunya terdapat dalam al-Qur' an surat al-Baqarah, sebagai berikut: Dan sempurnakanlah ibadah haji dan 'umroh karena Allah, (QS. AlBaqarah, 2:196). Bulan melakukan ibadah haji adalah setelah datangnya bulan untuk kewajiban berpuasa. Mengenai ayat-ayat tentang peperangan, untuk menjelaskan hukum yang berkaitan dengan bulan-bulan haram dan tentang Masjid al-Haram (Al-Maraghi, 1946). Ibadah haji dan umroh mempunyai imbalan yang besar di sisi Allah swt, terdapat dalam hadis Nabi Muhammad saw: Telah menceritakan kepada kami Abdullah ibn Yusuf, telah mengkhabarkan kepada kami Malik, dari Sumay hamba sahanya Abu Bakar ibn Abdurrahman, dari Abu Shalih as-Saman, dari Abu Hurairah ra, bahwasanya Rasul saw bersabda: Umroh kepada umroh yang berikutnya adalah suatu pengampunan dosa, sedangkan haji yang mabrur tiada balasan yang layak baginya selain surga (Al-Bukhary, 2008).

Permintaan yang begitu banyak serta kemudahan proses perjalanan haji dan umrah mengakibatkan meningkatnya jumlah biro travel khusus perjalanan ibadah tersebut. Masitah, (2015) menyatakan bahwa jika rata-rata dari setiap jamaah umrah biro travel mendapat keuntungan bersih USD300 saja, dengan jumlah jamaah sekitar 3.500 orang, maka keuntungan yang di dapat dalam setahun bisa lebih dari USD1 juta atau sekitar Rp. 9 miliar. Bahkan memiliki kesempatan dapat memperoleh margin yang lebih besar lagi, berhubung biro travel sering pula mendapatkan harga spesial dari penyelenggara haji dan umrah di Arab Saudi. Margin tersebut menjadi daya tarik tersendiri oleh para pelaku bisnis, sehingga perkembangan bisnis biro travel haji dan umrah di Indonesia sekarang ini memang meningkat secara signifikan.

Makassar merupakan salah satu kota padat penduduk dan mayoritas muslim sehingga animo masyarakat untuk menjalankan ibadah haji dan umrah sangat tinggi sehingga para pelaku bisnis biro travel haji dan umroh yang tidak bertanggung jawab dapat memanfaatkan situasi tersebut. Makassar pun telah banyak jamaah tertipu dengan harapan berangkat sekeluarga namun, tak seorangpun diberangkatkan, dan tidak hanya terjadi pada satu travel saja bahkan beberapa travel. Selain itu, calon jamaah tidak saja terlantar di bandara, namun fasilitas yang mereka dapatkan tidak sesuai dengan fasilitas yang telah disepakati. Lebih memprihatinkan lagi adanya penggelapan dana jamaah yang dilakukan oleh pemilik atau pengelola travel tersebut. Banyak dari jamaah tidak memiliki pengetahuan dalam menentukan pilihan terhadap biro travel yang 
amanah, profesional serta tidak mencari hanya keuntungan semata melainkan mengharap ridho dari Allah Swt. sehingga dalam menjalankan kegiatan bisnisnya menerapkan etika bisnis Islam yang sedapat mungkin dapat mendukung loyalitas jamaah serta mewujudkan kelangsungan usaha travel itu sendiri.

Terdapat beberapa penelitian terdahulu yang telah meneliti terkait etika bisnis Islam diantaranya (Che Omar dan Saripuddin, 2015), yang berjudul Concept Of Business Ethics In Islam - Approach To The Entrepreneur, hasil penelitian menunjukkan bahwa Konsep etika bisnis dalam Islam dapat menyadarkan seorang pengusaha. Pengusaha yang takut akan selalu tabah agar bisa mewujudkan kewirausahaan secara komprehensif dan sesuai syariat Islam. Oleh karena itu, setiap pengusaha harus senantiasa mengamalkan Islam berdasarkan al-Qur'an dan Sunnah serta selalu berakal, adil, jujur, amanah dan ikhlas dalam setiap pendirian usaha yang dilakukan dengan menjunjung tinggi nilai-nilai etika di kalangan pengusaha. (Anindya, 2017) meneliti pengaruh etika bisnis Islam terhadap keuntungan Usaha pada wirausaha di desa Delitua Kecamatan Delitua, hasil penelitian menyatakan bahwa setiap muslim pedagang harus menjalankan kegiatan ekonominya berdasarkan aturan atau ketetapan Syariah. (Zahrotul, 2017) melakukan penelitian dengan judul pengaruh penerapan etika bisnis Islam terhadap customer retention pada Baitul māl Wat tamwil (BMT) Tumang Boyolali, dengan hasil penelitian menyatakan untuk meningkatkan customer retention pada sebuah lembaga, dapat dilakukan dengan cara meningkatkan penerapan etika bisnis Islam dalam setiap operasional kegiatan. dan (Amir, 2018) dengan judul penelitian analisis pemahaman dan penerapan etika bisnis Islam pedagang pengepul barang bekas di kota Palembang, dalam penelitiannya menemukan faktor-faktor yang mempengaruhi pemahaman dan penerapan etika bisnis Islam pedagang pengepul barang bekas dapat dikategorikan baik.

Beberapa penelitian terdahulu terkait etika bisnis Islam belum terdapat penelitian yang mengkaji hubungan etika bisnis Islam terhadap kelangsungan usaha (Sustainability), sehingga menarik untuk melakukan penelitian lanjutan dengan objek kajian yang berbeda, objek penelitian ini tertuju pada bentuk penerapan etika bisnis secara Syariah yang diterapkan oleh pelaku bisnis travel haji dan umrah di kota Makassar. Selain itu penelitian ini menggunakan pendekatan kuantitatif dengan analisis Partial Least Square (PLS) dan metode studi penelitian lapangan, dimana model penelitian ini masih langka dilakukan oleh peneliti sebelumnya terkait etika bisnis Islam dan kelangsunga usaha (Sustainability). Penelitian ini dilakukan dengan maksud untuk menganalisis dan 
mengkonfirmasi bagaimana penerapan etika bisnis Islam terhadap loyalitas jamaah dan kelangsungan usaha biro travel haji dan umrah di kota Makassar.

\section{METODE PENELITIAN}

Penelitian ini dilaksanakan di kota Makassar khusus pada pelaku bisnis travel haji dan umrah. Sampel yang terpilih sebanyak 97 responden yang telah memenuhi kriteria penentuan sampel. Penelitian ini merupakan penelitian lapangan dengan menggunakan pendekatan kuantitatif, dan menggunakan alat analisis Structural Equation Modeling (SEM) yakni PLS (Partial Least Square) dalam menganalisis pengaruh penerapan etika bisnis Islam terhadap kelangsungan usaha. Penentuan sampel menggunakan teknik purpossive sampling dengan menentukan berapa kriteria diantaranya, terdaftar di Kementerian Agama Kota Makassar, Sudah berdiri $\geq 3$ tahun, Memiliki sturktur organisasi, serta Memiliki karyawan dalam menjalankan usahanya. Teknik pengumpulan data menggunakan kuesioner dan dokumentasi. Jenis data berupa data primer yaitu jawaban langsung dari responden pengelola travel haji dan umrah di kota Makassar melalu pertanyaan dalam bentuk kuesioner terkait prinsip keesaan, prinsip keadilan, prinsip kehendak bebas, prinsip bertanggung jawab, dan prinsip kebenaran yang diperoleh dari para pengelola biro travel haji dan umrah di kota Makassar. Teknik analisis data berupa statistik deskriptif, variabel independent terdiri dari: Prinsip keesaan (X1); Prinsip keadilan (X2); Prinsip kehendak bebas (X3); Prinsip bertanggung jawab (X4); Prinsip kebenaran (X5). Sedangkan, variable dependennya terdiri Kelangsungan loyalitas Jamaah (Y1), dan Kelangsungan Usaha (Y2). Berikut gambar model penelitian PLS. 
Gambar 1. Model Penelitian

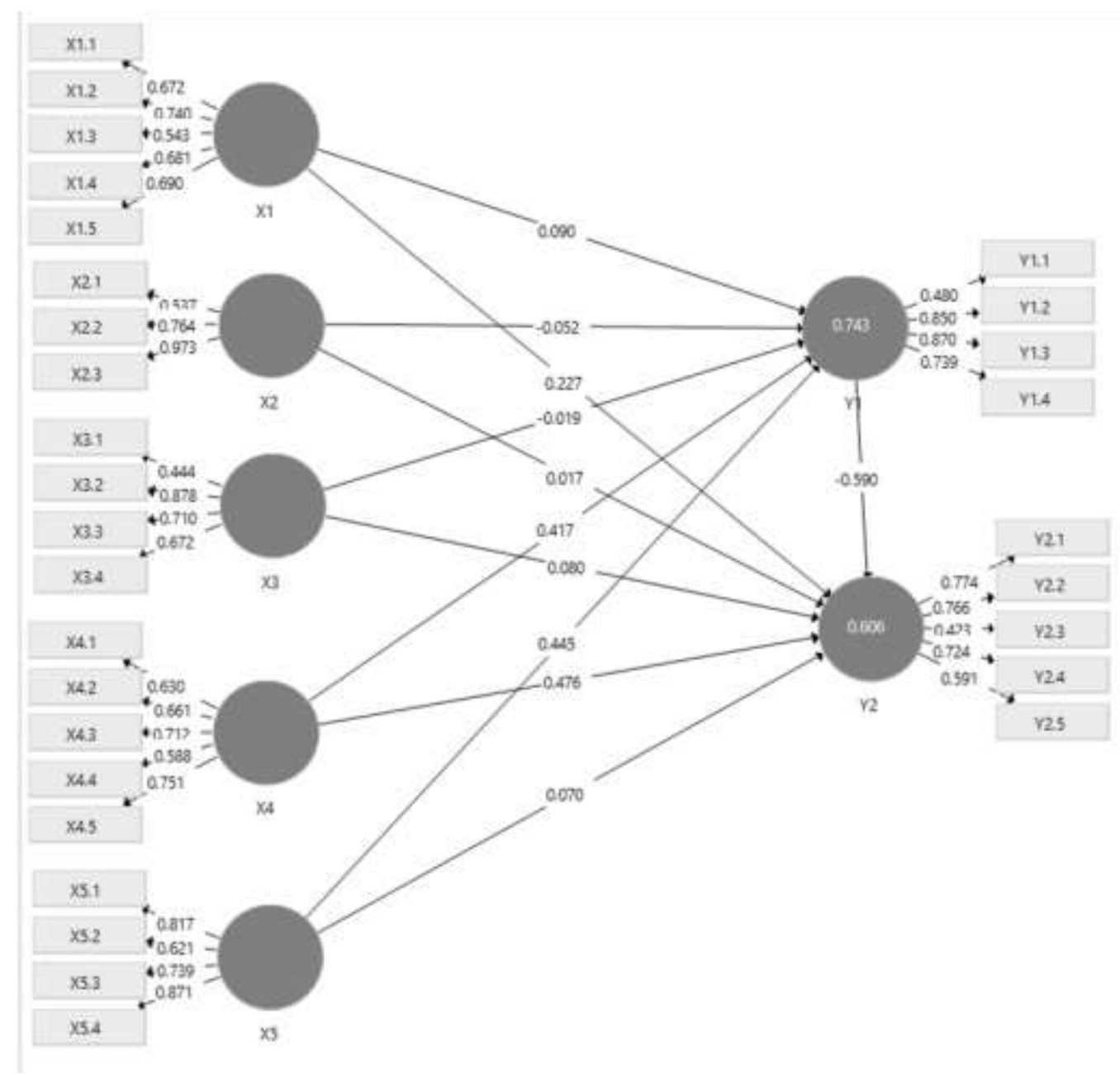

HASIL PENELITIAN DAN PEMBAHASAN

\section{Hasil Analisis Data dengan Pendekatan PLS}

Tahapan analisis PLS SEM menggunakan pengukuran outer model untuk uji validitas tahapan diantaranya, Convergent Validity, Discriminant Validity dan uji realibilitas yaitu Composite Realibility. Menurut (Jogiyanto, H.M. dan Abdillah, 2009) Pengukuran dapat dikategorikan mempunyai validitas konvergen apabila nilai loading factor $>0,7$ dan nilai AVE 0,5 dan validitas diskriminan ditentukan dengan mengamati nilai cross loading dari setiap variabel dan dikategorikan validitas diskriminan apabila memiliki nilai cross loading mencapai 0,7. Validitas Konvergen, Validitas konvergen adalah korelasi antara skor indikator dengan skor konstruknya. Analisis Model PLS SEM 
memiliki convergent validity dapat dinyatakan valid apabila nilai loading factor $>$ 0,7 dan nilai AVE 0,5. Hasil korelasi antara indicator dengan konstruknya menunjukkan nilai outer loading $>0,7$, yang dapat ditunjukkan pada tabel berikut ini:

Tabel 1. Hasil Pengujian Convergent Validity sebelum dan setelah Eliminasi

\begin{tabular}{|c|c|c|c|c|}
\hline Variabel & Indikator & Model Awal & $\begin{array}{c}\text { Modifikasi } \\
\quad(\geq 0,7)\end{array}$ & Keterangan \\
\hline \multirow[t]{5}{*}{ Prinsip Keesaan } & $\mathrm{X} 1.1$ & 0.672 & 0.767 & Diterima \\
\hline & X1.2 & 0.740 & 0.730 & Diterima \\
\hline & X1.3 & 0.543 & 0.740 & Diterima \\
\hline & X1.4 & 0.681 & 0.701 & Diterima \\
\hline & X1.5 & 0.690 & 0.798 & Diterima \\
\hline \multirow[t]{3}{*}{ Prinsip Keadilan } & $X 2.1$ & 0.537 & 0.707 & Diterima \\
\hline & $X 2.2$ & 0.764 & 0.771 & Diterima \\
\hline & $X 2.3$ & 0.973 & 0.977 & Diterima \\
\hline \multirow[t]{4}{*}{$\begin{array}{l}\text { Prinsip Kehendak } \\
\text { Bebas }\end{array}$} & X3.1 & 0.444 & & \\
\hline & X3.2 & 0.878 & 0.927 & Diterima \\
\hline & X3.3 & 0.710 & 0.768 & Diterima \\
\hline & X3.4 & 0.672 & 0.798 & Diterima \\
\hline Prinsip Bertanggung & $X 4.1$ & 0.630 & 0.732 & Diterima \\
\hline \multirow[t]{4}{*}{ Jawab } & $X 4.2$ & 0.661 & 0.765 & Diterima \\
\hline & $X 4.3$ & 0.712 & 0.713 & Diterima \\
\hline & $X 4.4$ & 0.588 & 0.787 & Diterima \\
\hline & $X 4.5$ & 0.751 & 0.745 & Diterima \\
\hline \multirow[t]{4}{*}{ Prinsip kebenaran } & X5.1 & 0.817 & 0.814 & Diterima \\
\hline & X5.2 & 0.621 & 0.716 & Diterima \\
\hline & X5.3 & 0.739 & 0.745 & Diterima \\
\hline & X5.4 & 0.871 & 0.873 & Diterima \\
\hline \multirow[t]{4}{*}{ Loyalitas Jamaah } & Y1.1 & 0.480 & & \\
\hline & Y1.2 & 0.850 & 0.885 & Diterima \\
\hline & Y1.3 & 0.870 & 0.860 & Diterima \\
\hline & Y1.4 & 0.739 & 0.760 & Diterima \\
\hline \multirow[t]{3}{*}{ Kelangsungan Usaha } & Y2.1 & 0.774 & 0.807 & Diterima \\
\hline & Y2.2 & 0.766 & 0.803 & Diterima \\
\hline & Y2.3 & 0.423 & & \\
\hline
\end{tabular}




$\begin{array}{llll}\text { Y2.4 } & 0.724 & 0.881 & \text { Diterima } \\ \text { Y2.5 } & 0.591 & 0.756 & \text { Diterima }\end{array}$

Sumber: Hasil Pengolahan dengan PLS, 2020

Pengolahan smart PLS dapat ditunjukkan pada tabel 1. Nilai outer model atau korelasi antara konstruk dengan variabel pada awalnya belum memenuhi konvergen validity karena beberapa indicator yang memiliki nilai loading factor dibawah 0.7, diantaranya X3.1, Y1.1, dan Y2.3, sehingga modifikasi model dilaksanakan dengan mengeluarkan indikator-indikator yang memikili nilai loading factor dibawah 0.70. pada model modifikasi sebagaimana ditunjukkan pada tabel 1. tersebut menunjukkan bahwa loading factor memiliki nilai di atas 0.70 , sehingga konstruk untuk semua variabel sudah tidak ada yang dieliminasi dari model.

\section{Discriminant Validity}

Model pengukuran reklektif indikator discriminant validity dapat diukur berdasarkan nilai AVE (Average Variance Extracted) Discriminant validity digunakan untuk mengukur korelasi konstruk yaitu, dalam mengidentifikasi indikator tertinggi dalam suatu variabel. Pengujian validitas konvergen dapat diamati dari nilai AVE (Average Variance Extracted).variabel dalam penelitian ini memiliki AVE $>0,5$. Nilai AVE dalam model yang dapat ditunjukkan pada tabel 2 berikut:

Tabel 2. Hasil Uji AVE (Average Variance Extracted)

\begin{tabular}{lc}
\hline \multicolumn{1}{c}{ Variabel } & AVE $(>\mathbf{0 , 5 )}$ \\
\hline Prinsip Keesaan & 0.547 \\
Prinsip Keadilan & 0.602 \\
Prinsip Kehendak Bebas & 0.554 \\
Prinsip Bertanggung Jawab & 0.550 \\
Prinsip Kebenaran & 0.590 \\
Loyalitas Jamaah & 0.700 \\
Kelangsungan Usaha & 0.547 \\
\hline Sumber: Hasil Pengolahan dengan PLS, Tahun 2020
\end{tabular}

Data yang tersaji pada table 1 dan 2 di atas, maka dapat disimpulkan bahwa berdasarkan nilai outer loading dan EVA, data penelitian ini telah memenuhi persyaratan pengujian validitas konvergen.

Composite Reliability

Composite Reliability merupakan uji reliabilitas yang menggambarkan akurasi serta tingkat konsistensi dari ketetapan suatu alat ukur didalam 
pengukuran. Jika nilai composite reliability masing-masing variabel $>0,7$ maka Composite Reliability-nya baik, hasil uji composite reliability dapat diamati pada table 3 berikut.

Tabel 3. Hasil Uji Composite Reliability

\begin{tabular}{lc}
\hline \multicolumn{1}{c}{ Variabel } & $\begin{array}{c}\text { Composite } \\
\text { Reliability }(>\mathbf{0 , 7})\end{array}$ \\
\hline Prinsip Keesaan & 0.800 \\
Prinsip Keadilan & 0.810 \\
Prinsip Kehendak Bebas & 0.782 \\
Prinsip Bertanggung Jawab & 0.802 \\
Prinsip Kebenaran & 0.850 \\
Loyalitas Jamaah & 0.875 \\
Kelangsungan Usaha & 0.827 \\
\hline Sumber: Hasil Pengolahan dengan PLS, Tahun 2020
\end{tabular}

\section{Model Partial Least Square (PLS)}

PLS merupakan Structural Equation Modeling (SEM) yang memiliki metode pendekatan alternatif dari basis kovarian ke basis varian. Penelitian ini menggunakan software SmartPLS3 dalam menguji model struktural dalam PLS. Tahap pertama yang perlu dilakukan dalam permodelan PLS yakni membuat spesifikasi model dengan membuat rancangan inner model atau outer model. Inner model sebagai struktur penghubung antara variabel laten pada substantive teori yaitu, variabel independen $(X)$ terhadap variabel dependen $(Y)$ , variabel $X$ dalam penelitian ini diantaranya prinsip keesaan (X1), prinsip keadilan (X2), prinsip kehendak bebas (X3), prinsip bertanggung jawab (X4), dan prinsip kebenaran (X5) sedangkan, variabel dependen yaitu loyalitas jamaah (Y1), dan kelangsungan usaha (Y2). Selanjutnya proses eliminasi dilakukan untuk membuang atau mengeleminasi yang nilainya dibawah standar nilai dengan teknik bootstrap, dapat diamati pada tabel berikut ini: 
Tabel 4. Nilai Loading Faktor Setelah Eliminasi dan Hasil Bootstrap Indikator Variabel dan Indikator Laten

\begin{tabular}{|c|c|c|c|}
\hline Variabel & Indikator & $\begin{array}{l}\text { Setelah } \\
\text { eliminasi }\end{array}$ & $\begin{array}{c}\text { Hasil } \\
\text { Bostrap }\end{array}$ \\
\hline \multirow[t]{5}{*}{ Prinsip Keesaan } & X1.1 & 0.672 & 0.767 \\
\hline & $\mathrm{X} 1.2$ & 0.740 & 0.730 \\
\hline & $\mathrm{X} 1.3$ & 0.543 & 0.740 \\
\hline & $\mathrm{X} 1.4$ & 0.681 & 0.701 \\
\hline & X1.5 & 0.690 & 0.798 \\
\hline \multirow[t]{3}{*}{ Prinsip Keadilan } & $X 2.1$ & 0.537 & 0.707 \\
\hline & $\mathrm{X} 2.2$ & 0.764 & 0.771 \\
\hline & $\mathrm{X} 2.3$ & 0.973 & 0.977 \\
\hline \multirow[t]{4}{*}{$\begin{array}{l}\text { Prinsip Kehendak } \\
\text { Bebas }\end{array}$} & X3.1 & 0.444 & \\
\hline & X3.2 & 0,878 & 0.927 \\
\hline & X3.3 & 0,710 & 0.768 \\
\hline & X3.4 & 0,672 & 0.798 \\
\hline Prinsip Bertanggung & $X 4.1$ & 0,630 & 0.732 \\
\hline \multirow[t]{4}{*}{ Jawab } & $X 4.2$ & 0,661 & 0.765 \\
\hline & $X 4.3$ & 0,712 & 0.713 \\
\hline & $X 4.4$ & 0,588 & 0.787 \\
\hline & $X 4.5$ & 0,751 & 0.745 \\
\hline \multirow[t]{4}{*}{ Prinsip kebenaran } & X5.1 & 0.817 & 0.814 \\
\hline & $\mathrm{X} 5.2$ & 0.621 & 0.716 \\
\hline & $X 5.3$ & 0.739 & 0.745 \\
\hline & X5.4 & 0.871 & 0.873 \\
\hline \multirow[t]{4}{*}{ Loyalitas Jamaah } & Y1.1 & 0.480 & \\
\hline & Y1.2 & 0.850 & 0.885 \\
\hline & Y1.3 & 0.870 & 0.860 \\
\hline & Y1.4 & 0.739 & 0.760 \\
\hline \multirow[t]{5}{*}{ Kelangsungan Usaha } & Y2.1 & 0.774 & 0.807 \\
\hline & Y2.2 & 0.766 & 0.803 \\
\hline & Y2.3 & 0,423 & \\
\hline & Y2.4 & 0,724 & 0.881 \\
\hline & Y2.5 & 0,591 & 0.756 \\
\hline
\end{tabular}

Sumber: Hasil Pengolahan dengan PLS, Tahun 2020 
Setelah mengamati hasil analisis permodelan PLS pada tabel 4. di atas terkait etika bisnis Islam terhadap Y1. Loyalitas jamaah dan Y2. Kelangsungan Usaha, maka dalam penelitian ini terlihat bahwa semua indikator yang digunakan telah memenuhi kriteria dari rule of thumb dan kriteria convergent validity yang memiliki angka faktor loading $>0,5$. Diagram jalur setelah hasil dari permodelan PLS setelah bootstrap sebagai berikut.

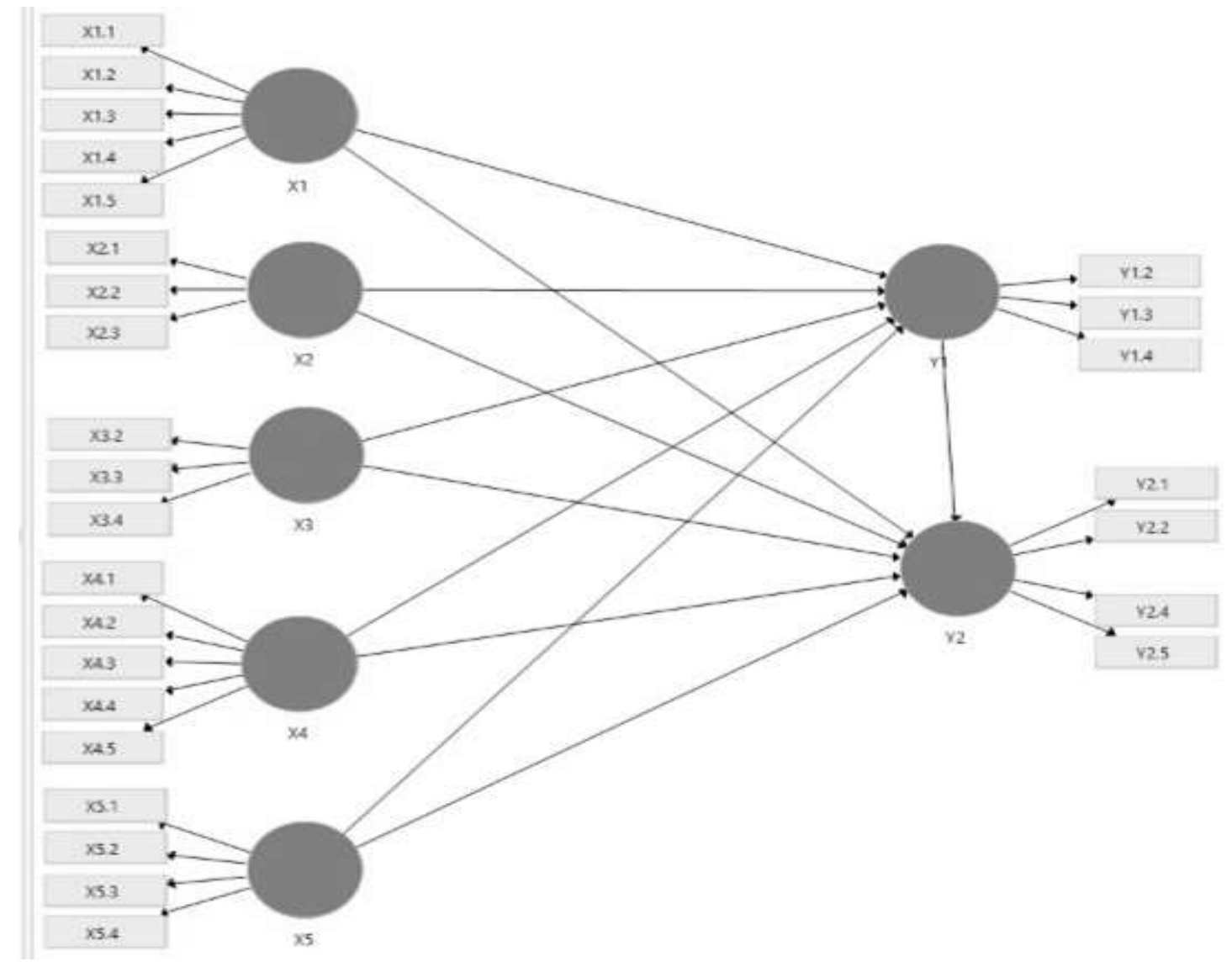

\section{Evaluasi Goodness of Fit Model Struktural (Inner Model)}

Evaluasi Goodness of Fit pada tahapan inner model, untuk mengukur model struktural yang dilakukan sebagai pengukuran dengan menggunakan $R$-Square variabel laten dependen, yang bertujuan untuk mengukur seberapa baik nilai dari observasi yang telah dihasilkan dari model.

\section{Pengujian Hipotesis}

Uji hipotesis digunakan untuk menguji pengaruh secara parsial dari variabel $X$ terhadap variabel $Y$ untuk melihat nilai t-values pada setiap path. Nilai t-hitung didapat dari hasil setelah bootstraping dengan menggunakan software SmartPLS3, untuk meminimalkan masalah ketidaknormalan data penelitian makan digunakan pengujian bootstrap. Tingkat keyakinan sebesar 95\% maka koefisien inner weight dari model 
struktural dinyatakan siignifikan jika t-hitung $>$ t-tabel sebesar 1,96 atau 2,000. Hasil pengujian hipotesis penelitian dapat dilihat pada table berikut.

Tabel 4. Hasil Uji Hipotesis

\begin{tabular}{|c|c|c|c|c|}
\hline $\begin{array}{c}\text { Variabel } \\
\text { Independen }\end{array}$ & $\begin{array}{l}\text { Variabel } \\
\text { Dependen }\end{array}$ & $\begin{array}{c}\text { Koefisien } \\
\text { Inner } \\
\text { Weight }\end{array}$ & $\begin{array}{c}\text { t- } \\
\text { hitung }\end{array}$ & Keterangan \\
\hline $\begin{array}{l}\text { Prinsip } \\
\text { Keesaan }\end{array}$ & $\begin{array}{l}\text { Loyalitas } \\
\text { Jamaah }\end{array}$ & 0,065 & 1,831 & $\begin{array}{l}\text { Responden tidak setuju prinsip } \\
\text { keesaan berpengaruh terhadap } \\
\text { loyalitas jamaah pada biro } \\
\text { travel haji dan umrah di kota } \\
\text { Makassar }\end{array}$ \\
\hline $\begin{array}{l}\text { Prinsip } \\
\text { Keadilan }\end{array}$ & $\begin{array}{l}\text { Loyalitas } \\
\text { Jamaah }\end{array}$ & 0,078 & 0,522 & $\begin{array}{l}\text { Responden tidak setuju prinsip } \\
\text { keadilan berpengaruh terhadap } \\
\text { loyalitas jamaan } \mathrm{p}\end{array}$ \\
\hline $\begin{array}{l}\text { Prinsip } \\
\text { Kehendak } \\
\text { Bebas }\end{array}$ & $\begin{array}{l}\text { Loyalitas } \\
\text { Jamaah }\end{array}$ & 0,082 & 0,286 & $\begin{array}{l}\text { Responden tidak setuju prinsip } \\
\text { kehendak bebas berpengaruh } \\
\text { terhadap loyalitas jamaah pada } \\
\text { biro travel haji dan umrah di } \\
\text { kota Makassar }\end{array}$ \\
\hline $\begin{array}{l}\text { Prinsip } \\
\text { Bertanggung } \\
\text { Jawab }\end{array}$ & $\begin{array}{l}\text { Loyalitas } \\
\text { Jamaah }\end{array}$ & 0,094 & 3,401 & $\begin{array}{l}\text { Responden setuju prinsip } \\
\text { bertanggung jawab } \\
\text { berpengaruh terhadap loyalitas } \\
\text { jamah pada biro travel haji } \\
\text { dan umrah di kota Makassar }\end{array}$ \\
\hline $\begin{array}{l}\text { Prinsip } \\
\text { Kebenaran }\end{array}$ & $\begin{array}{l}\text { Loyalitas } \\
\text { Jamaah }\end{array}$ & 0,102 & 4,93 & $\begin{array}{l}\text { Responen setuju prinsip } \\
\text { kebenaran berpengaruh } \\
\text { terhadap loyalitas jamaan pada } \\
\text { biro travel haji dan umrah di } \\
\text { kota Makassar }\end{array}$ \\
\hline $\begin{array}{l}\text { Prinsip } \\
\text { Keesaan }\end{array}$ & $\begin{array}{l}\text { Kelangsungan } \\
\text { Usaha }\end{array}$ & 0,122 & 2,008 & $\begin{array}{l}\text { Responden setuju prinsip } \\
\text { keesaan berpengaruh terdahap } \\
\text { kelangsungan usaha pada biro } \\
\text { travel haji dan umrah di kota } \\
\text { Makassar }\end{array}$ \\
\hline
\end{tabular}




\begin{tabular}{|c|c|c|c|c|}
\hline & & & & Responden tidak setuju prinsip \\
\hline $\begin{array}{l}\text { Prinsip } \\
\text { Keadilan }\end{array}$ & $\begin{array}{l}\text { Kelangsungan } \\
\text { Usaha }\end{array}$ & 0,075 & 0,551 & $\begin{array}{l}\text { keadilan berpengaruh terhadap } \\
\text { kelangsungan usaha pada biro } \\
\text { travel haji dan umrah di kota } \\
\text { Makassar }\end{array}$ \\
\hline $\begin{array}{l}\text { Prinsip } \\
\text { Kehendak } \\
\text { Bebas }\end{array}$ & $\begin{array}{l}\text { Kelangsungan } \\
\text { Usaha }\end{array}$ & 0,093 & 1,120 & $\begin{array}{l}\text { Responden tidak setuju prinsip } \\
\text { kehendak bebas berpengaruh } \\
\text { terhadap kelangsungan usaha } \\
\text { pada biro travel haji dan umrah } \\
\text { di kota Makassar }\end{array}$ \\
\hline $\begin{array}{l}\text { Prinsip } \\
\text { Bertanggung } \\
\text { Jawab }\end{array}$ & $\begin{array}{l}\text { Kelangsungan } \\
\text { Usaha }\end{array}$ & 0,115 & 5,152 & $\begin{array}{l}\text { Responden setuju prinsip } \\
\text { bertanggung jawab terhadap } \\
\text { kelangsungan usaha pada biro } \\
\text { travel haji dan umrah di kota } \\
\text { Makassar }\end{array}$ \\
\hline $\begin{array}{l}\text { Prinsip } \\
\text { Kebenaran }\end{array}$ & $\begin{array}{l}\text { Kelangsungan } \\
\text { Usaha }\end{array}$ & 0,171 & 2,115 & $\begin{array}{l}\text { Responden setuju prinsip } \\
\text { kebenaran } \quad \text { berpengaruh } \\
\text { terhadap kelangsungan usaha } \\
\text { pada biro travel haji dan umrah } \\
\text { di kota Makassar }\end{array}$ \\
\hline
\end{tabular}

\section{KESIMPULAN}

Hasil penelitian penerapan etika bisnis Islam terhadap loyalitas jamaah dan kelangsungan usaha pada biro travel haji dan umrah di kota Makassar, dapat disimpulkan bahwa para pengelola bisnis travel haji dan umrah dalam mengelola bisnisnya telah menjalankan sistem dan kinerja yang berpegang pada prinsip Syariah, memberikan pelayanan yang trasfaran terhadap jamaah baik dari segi administrasi maupun keuangan, melayani semua jamaah secara ramah, professional serta penuh dengan rasa kekeluargaan. Hal ini merupakan hasil yang sangat menggembirakan bagi semua calon jamaah haji dan umrah di kota Makassar. Mengingat Makassar merupakan salah satu kota padat penduduk dan mayoritas muslim sehingga animo masyarakat untuk menjalankan ibadah haji dan umrah sangat tinggi, yang tentunya tidak perlu khawatir lagi akan terjadinya penipuan. Menjalankan sistem dan kinerja yang berpegang teguh pada prinsip Syariah tentunya dapat menunjang kelangsungan usaha travel 
yang mereka jalankan. Namun di sisi lain, pengaruhnya terhadap loyalitas jamaah belum signifikan hal ini menunjukkan para jamaah cenderung tidak konsisten memilih salah satu biro travel yang digunakan sebagai fasilitator penjalanan ibadah umrahnya ke Baitullah.

\section{DAFTAR PUSTAKA}

Agama, K. (2012). Al-Qur'anul Karim Tafsir Per Kata Tajwid Kode (Cetakan 3). Yayasan Qiblat Al Khairiyyah.

Al-Bukhary. (2008). Al-Jami ash-Shahih al-Musnad min Hadits Rasulullah Shallallah 'Alaihi wa Sallam wa Sunanih wa Ayyamih. Juz VI. Dar al-Kutub.

Al-Maraghi. (1946). Tafsir al-Maraghi. Juz II (1st ed.). Syirkah Maktabah wa Mathba ah Musthafa al-Bab al-Halb wa Awaladih.

Amir, S. (2018). Analisis Pemahaman dan Penerapan Etika Bisnis Islam Pedagang Pengepul Barang Bekas di Kota Palembang. Islamic Banking, 4.

Anindya, D. A. (2017). Pengaruh Etika Bisnis Islam terhadap Keuntungan Usaha Pada Wirausaha di Desa Delitua Kecamatan Delitua. At-Tawassuth, 2.

Ath-Thabary. (2001). Tafsir ath-Thabary; Jami al-Bayan 'an Ta'wil Ay Alquran. Juz III (1st ed.). Markaz al-Buhuts wa ad-Dirasah al-`Arabiyah wa Islamiyah.

Che Omar, C. M. Z., \& Saripuddin, A. S. S. (2015). Concept of Business Ethics in Islam - Approach To the Entrepreneur 2 . Sources of Islamic Business Ethics. Journal of Asian Business Strategy, 5(1), 13-18.

Fadilah, L. (2019). Strategi dan Manajemen Travel Haji dan Umrah (Studi Analisis Persaingan Travel Haji Dan Umroh Kota Medan Dalam Pelayanan dan Kualitas Untuk Meningkatkan Jumlah Konsumen). AlMuamalat Jurnal Hukum Ekonomi Syariah, 4, 3.

Jogiyanto, H.M. dan Abdillah, W. (2009). Konsep dan Aplikasi PLS (Partial Least Square) untuk Penelitian Empiris. BPFE-Yogyakarta.

Masitah, D. (2015). Dinamika Bisnis Travel Umroh Se Kota Pasuruan Di Era Globalisasi. Iqtishadia: Jurnal Ekonomi E Perbankan Syariah, 2(2), 242. 
Nurbayani: Sustainibility; Ethics; Business;Hajj And Umrah

Qordhowi, Y. (1993). Norma dan Etika Ekonomi Islam. Gema Insani Press.

Rahmad, Hakim \& Elvan, S. (2012). Business As Al-Amanah And The Responsibilitiesof Islamic Business Managers. La_Riba: Jurnal Ekonomi Islam, 6, 208.

Sabahuddin, A. (2005). An Islamic Approach to Business Ethics. Pakistan: Renaissance a Monthly Islamic Journal, 1(1), 1.

Sirajuddin, S., \& Tamsir, T. (2019). Rekonstruksi Konseptual Kepemilikan Harta Perspektif Ekonomi Islam (Studi Kritis Kepemilikan Harta Sistem Ekonomi Kapitalisme). Laa Maisyir: Jurnal Ekonomi Islam, 6(2), 211-225.

Zahrotul, W. (2017). Pengaruh Penerapan Etika Bisnis Islam Terhadap Customer Retention Pada Baitul Māl Wat Tamwil (Bmt) Tumang Boyolali. Institut Agama Islam Negeri (Iain) Surakarta. 